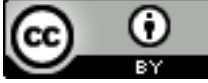

\title{
TEORIA CRÍTICA DE CURRÍCULO EM GIROUX COMO ENFRENTAMENTO DO ESPAÇO dE REPRODUÇÃO NA FORMAÇÃO CONTINUADA DE PROFESSORES
}

\author{
CRITICAL THEORY OF CURRICULUM IN GIROUX AS FACING THE SPACE OF \\ REPRODUCTION IN THE CONTINUED TEACHER TRAINING
}

\section{TEORÍA CRÍTICA DEL CURRÍCULO EN GIROUX COMO FRENTE AL ESPACIO DE REPRODUCCIÓN EN LA FORMACIÓN CONTINUA DE MAESTROS}

\section{Rudinei Barichello Augusti ${ }^{\text {i }}$}

RESUMO: Este artigo tem como objetivo apresentar e discutir a Teoria Crítica e sua construção a partir da Escola de Frankfurt, o Currículo em Giroux, a Formação continuada de professores, suas implicações teóricasbibliográficas e, por fim, como ocorre o enfrentamento da reprodução no âmbito da formação continuada de professores. Apresenta os teóricos da Escola de Frankfurt, com sua centralidade nas questões curriculares analisadas por Henry Giroux. Discute a importância da Teoria Crítica como elemento central no Currículo de Formação continuada de professores, bem como o enfrentamento da reprodução a partir da racionalidade técnica. Por último, cabe dizer, na perspectiva da reflexão crítica, que os professores avançam em um processo de enfrentamento quando superam a racionalidade técnica por meio da reflexão sobre sua prática e sua formação continuada a partir da pesquisa-ação.

PALAVRAS-CHAVE: Teoria crítica. Currículo em Giroux. Formação continuada de professores.

ABSTRACT: This article aims to present and discuss the Critical Theory and its construction from the Frankfurt School, the Curriculum in Giroux, the Continuing Teacher Education, its theoretical and bibliographic implications, and, finally, how coping with reproduction in the scope Teacher training. It presents the theorists of the Frankfurt School, with its centrality in the curricular questions analyzed by Henry Giroux. It discusses the importance of Critical Theory as a central element in the Curriculum of Continuing Teacher Education, as well as coping with reproduction based on technical rationality. Finally, it is worth mentioning, in the perspective of critical reflection, that teachers advance in a process of confrontation when they overcome technical rationality by means of reflection on their practice and their ongoing formation from action research.

KEYWORDS: Critical theory. Curriculum in Giroux. Continuing teacher training.

RESUMEN: Este artículo tiene como objetivo presentar y discutir la teoría crítica y su construcción de la Escuela de Frankfurt Curriculum en Giroux, la formación continua de los profesores, sus implicaciones teóricobibliográficos y, por último, al igual que en la cara de reproducción con arreglo la formación continua de los profesores. Presenta el teórico de la Escuela de Frankfurt, con su centralidad en cuestiones curriculares examinados por Henry Giroux. Se analiza la importancia de la teoría crítica como un elemento central en el plan de estudios de la formación continua de los profesores, así como hacer frente a la reproducción desde la racionalidad técnica. Por último, hay que decir, desde la perspectiva de la reflexión crítica, los maestros avanzan en el proceso de hacer frente al superar la racionalidad técnica a través de la reflexión sobre su práctica y su educación continua de la investigación-acción.

PALABRAS CLAVE: Teoría crítica. Curiculo en Giroux. La formación continua del profesorado.

Submetido em: 21/01/2017 - Aceito em: 26/06/2017 - Publicado em: 29/06/2017.

\begin{tabular}{l|c|c|c|c|c|} 
(C) Rev. Inter. Educ. Sup. & Campinas, SP & v.3 & n.2 & p.255-269 & maio/ago. 2017 \\
\hline
\end{tabular}




\section{INTRODUÇÃo}

A crescente gama de estudos e pesquisas sobre a formação continuada de professores, demonstra nos últimos tempos, a partir das perspectivas da teoria crítica, a emergência da contestação às abordagens tradicionais de currículo, entendido como técnico, positivista e de racionalidade instrumental. Busca-se aqui possibilitar, através da discussão de elementos bibliográficos inseridos no arcabouço da nova sociologia e na teoria crítica de Currículo de Henry Giroux, o enfrentamento da reprodução na formação continuada de professores.

Quando visualizado o cenário da formação continuada de professores, em especial sua compreensão curricular, parece ainda persistir a racionalidade técnica bem como o conformismo e a naturalização das relações de reprodução. Entretanto, há uma tensão entre a abordagem crítica da formação continuada, em especial na compreensão de Giroux, e no entendimento de Currículo de formação continuada como espaço de reprodução. Apesar do dilema permanecer sempre aberto à debates, essa tensão gera o enfrentamento, quisá em uma perspectiva futura, a sua superação. Dessa forma, pode-se dizer, no entanto, que a melhoria dos processos de formação continuada podem ser associados ao enfrentamento.

Com a intenção do debate em torno das possibilidades de enfrentamento e superação da abordagem de reprodução presente no currículo de formação continuada, esta proposta de reflexão busca trilhar caminhos que vão desde a construção da Teoria Crítica a partir da Escola de Frankfurt. Em seguida, apresenta Henry Giroux e sua abordagem de Currículo como um de seus continuadores que culminando com o debate em torno da formação continuada proposta pelo mesmo autor.

Este estudo não quer ser exaustivo por sua dinâmica, mas informativo e reflexivo, conduzindo o leitor à uma abordagem crítica, apoiada na historicidade da Teoria Crítica, bem como inserindo nela, o debate em torno do Currículo de Formação continuada de professores. As questões que foram levantadas dizem respeito às contribuições de Henry Giroux e outros teóricos que vão culminar na existência e identificação dos novos caminhos para a formação continuada de professores.

Desta forma, este estudo tem como objetivo possibilitar algumas reflexões em torno do referencial teórico crítico, em especial, de Giroux, sobre a formação continuada de professores, seja quanto ao resgate da construção histórica da Teoria Crítica e seus pressupostos, seja, tópicos que buscam debater a racionalidade técnica presente nos currículos de formação continuada de professores.

Por fim, cabe dizer que, mesmo de forma rápida, é necessário apresentar o legado da Escola de Frankfurt, sua história e Epistemologia, intencionando os percursos e a produção histórica, social e dialeticamente construída, que deram origem à Teoria Crítica, para depois inserir no campo do currículo de formação continuada de professores.

V.3

n.2




\section{A TEORIA CRÍTICA: SUA HISTÓRIA E EPISTEMOLOGIA}

A Teoria Crítica surge em 1924, associada à Sociologia Alemã, tendo como local a Escola de Frankfurt, na época denominada Instituto de Pesquisas Sociais. A Escola de Frankfurt nasceu por iniciativa de um grupo de intelectuais que tinham princípios em comum. Um aspecto em comum era que todos derivavam de famílias de tradição judia. Alguns dos pensadores da Escola de Frankfurt eram remanescentes de famílias burguesas. Em virtude disso, tinham possibilidade de estudar em Universidades conceituadas de seu tempo, sobretudo, na Universidade de Frankfurt entre outras da Alemanha e de todo o mundo.

As teorias pensadas e discutidas por essa escola transcendem ao seu tempo, chegando aos nossos dias, e são importantes para compreender os fenômenos do mundo atual. Muitas vezes, os intelectuais sociais contemporâneos, comprometidos com a luta social, com o desenvolvimento e o progresso, resgatam questões fundamentais da Escola de Frankfurt. Perguntas como resolver as relações de conflito entre dominantes e dominados, em um sistema social conflitante fazem parte da dimensão dos estudos oriundos da Escola de Frankfurt. Além das questões sempre abertas, a abordagem dialética permite pensar, porque diante desse cenário, as pessoas não reagem? Em tentativa de responder, é que existe um sistema que manipula, domina e, sobretudo, há um processo profundo de alienação. Nesse sentido, emerge outra questão importante: compreender como se há chegado à esses limites da alienação, em que as pessoas se sentem satisfeitas. Para responder à esses e outros questionamentos, os teóricos críticos pensam encontrar fundamentação na Escola de Frankfurt.

Os intelectuais da Escola de Frankfurt dedicaram-se basicamente à isso: discutir, analisar, estudar os pontos ocultos da dominação capitalista. Assim, percebe-se que esses intelectuais, independente de suas atividades intelectuais individuais, estavam preocupados em compreender a profunda dominação capitalista que ocorria na Alemanha no início do Século XX. Apesar de os teóricos da Escola de Frankfurt terem em comum a preocupação acima descrita, cada um deles tentou encontrar um espaço de debate a partir de uma preocupação central.

A Escola de Frankfurt nasce como nomeada de "Instituto de Investigação Social de Frankfurt". Traz consigo o privilégio da vida universitária institucional, porque não havia precedentes da criação de um Instituto de orientação marxista institucionalizado em uma universidade com tal prestígio como era seu caso. Isto foi possível pois, por trás desse esforço, estava um milionário alemão chamado Félix Weil (1898-1975), intelectual e filósofo marxista, que, filho de um importante industrial, havia se inclinado ao marxismo. No entanto, Félix Weil não apenas tinha dinheiro, mas poder de convencimento, ao convencer as autoridades universitárias para criar um instituto que se encarregue de fazer investigações sociais dos mais variados problemas que surgiram com o capitalismo. Diante disso, 
autoridades de Frankfurt encarregam-se de criar um edifício com biblioteca de mais de trinta e sete mil volumes de obras. Por fim, Félix Weil empreende um esforço econômico e intelectual muito singular, ao convidar Carl Jung (1875-1961) para ser o primeiro gestor do Instituto. Posteriomente, a direção do Instituto fica nas mãos de quem lhe deu um impulso muito importante que é Max Horkheimer (1895-1973). No mesmo ano, apoiado por Félix Weil, Horkheimer dedica o seu trabalho à fortalecer a Escola, convidando outro intelectual musicólogo chamado Theodor Adorno (1903-1969). Adorno estudou Filosofia, obtendo o título de Doutor. Adorno em sua atividade intelectual têm suas principais obras vinculadas à Filosofia da Arte, em especial, a estética filosófica. Por investigar a Estética, entra em contato com Georg Luckács.

A Escola de Frankfurt tem como pretensão produzir e realizar fóruns/debates, conferências em/com outras universidades, chamando outros intelectuais que tinham proposições teóricas comuns à eles: judeus e marxistas no sentido de críticos do marxismo oficial.

Faz parte também da Escola de Frankfurt outro intelectual que se destaca pelo estudo do judaísmo, Erich Fromm (1900-1980). Formado em Psicologia, investigou as obras de Sigmund Freud, em especial, àquelas que tratam da psicanálise, Gestalt e todas as correntes de investigação da psicologia de seu tempo. Estudou também Filosofia. Após Fromm, a Escola de Frankfurt consegue combinar, de forma curiosa, o Judaísmo com o Marxismo, o que produziu o pensamento humanista para o Século XX, que se estende ao XXI.

Em comum, Horkheimer, Adorno, Luckács e Erich Fromm contribuíram de forma particular com sua disciplina à descobrir os signos ocultos da dominação do capitalismo, em forma de crítica à alienação. Para tal, Adorno e Horkheimer criam categorias. A categoria razão instrumental é uma delas. Adorno e Horkheimer escrevem juntos "Dialética do Iluminismo", onde realizam uma crítica ao afã que temos dos humanos, em que o imperativo de construir a felicidade ocorre com base nas condições materiais; ou seja, a ideia de progresso que temos, é a ideia de satisfazer todos os desejos e necessidades pessoais e sociais, chamada de modernismo, quando a humanidade propõe construir a felicidade através do uso da razão. $\mathrm{O}$ privilégio do racional em que paira a crença de que a ciência e a tecnologia vão nos levar à construir um mundo cada vez mais feliz.

Duas obras que se destacam em Horkheimer, com contribuições de Adorno, são a "Dialética do Iluminismo" e a "Crítica da Razão Instrumental". Na Dialética do Iluminismo, há uma compreensão sobre o mesmo, onde afirma que o Iluminismo,

No sentido mais amplo do progresso do pensamento, o esclarecimento tem perseguido sempre o objetivo de livrar os homens do medo e de investi-los na posição de senhores. Mas a terra totalmente esclarecida resplandece sob o signo de uma calamidade triunfal (ADORNO E HORKHEIMER, 1985, p. 13). 
Outros pensadores também constituíram a Escola de Frankfurt. Entre eles, encontramos ainda Herbert Marcuse (1898-1979) que produziu seus pensamentos em outros países, uma vez que a Alemanha se encontrava em guerra. Quando sai da Alemanha, seu trabalho intelectual foi acolhido por universidades nos Estados Unidos. Sua obra principal é chamada "O homem Unidimensional", onde faz uma crítica ao marxismo mecanicista - marxismo dos partidos dominantes. Seus estudos estavam centrados em três fases: Marx Humanista, Marx Jovem e Marx Adulto. São produções próximas de Hegel, mas que não aproxima Marx de Hegel. Nesse sentido, Marcuse critica o marxismo, afirmando de que o proletariado vai converter-se em uma classe revolucionária por excelência; ou como diz Marx, o proletariado é o sujeito da revolução.

Quando Marcuse chega nos Estados Unidos em 1950, encontra um cenário acelerado de desenvolvimento industrial. Isto se deve ao fato de que os Estados Unidos saiu favorecido da II Guerra Mundial, uma vez que se aproveitou da II Guerra Mundial para se nutrir de todos os elementos industriais para a guerra. Devido à isso, os Estados Unidos tinham em seu interior uma classe trabalhadora industrial organizada em sindicatos, poderosa politicamente, e que reclamavam seus direitos. Marcuse percebe que o proletariado dos Estados Unidos vive em condições favoráveis economicamente, e sobre isto, começa a elaborar sua tese sobre o sujeito da revolução, afirmando de que não há diferença enquanto consciência burguesa entre um proletário e um burguês. Segundo Marcuse, o proletário quer ser burguês, uma vez que vivenciou, mesmo que em menor escala, os benefícios do capitalismo. E então, tem-se anulado enquanto sujeito da revolução. Sinteticamente, essa é a tese central do homem unidimensional de Marcuse. Essa compreensão posteriormente foi criticada, pois está restrita à uma condição muito particular dos Estados Unidos.

Ainda sobre Erich Fromm, apresentado anteriormente, quando no México, escreve vários livros, entre eles "Ter ou Ser", onde expressa sua perspectiva humanista socialista; ou seja, um socialismo jamais desapegado do humano.

Sobre a importância da diferença entre ter e ser, consideramos que as alternativas entre ter e ser se opõe e, portanto, não atrai o senso comum. Parece que ter é uma função normal da vida, para viver, devemos ter coisas. Além disso, devemos tê-las para desfrutá-las. Numa cultura cuja meta suprema é ter (cada vez mais), e na qual pode-se dizer que alguém "vale um milhão de dólares", como pode haver uma alternativa entre ter e ser? Pelo contrário, parece que a própria essência de ser consiste em ter, e se o indivíduo não tem nada, não é ninguém. (FROMM, 1977, p. 26)

Nos anos de 1960, quando Erich Fromm escreve esta obra, começa a perceber que todas as perspectivas estão dizendo de que o modernismo está equivocado, pois existe o predomínio da coisa sobre o ser, o que, em seu entendimento não é justo, é equivocado. Nesse sentido, podemos dizer de que a contribuição de Fromm está no sentido de humanizar o mundo, que contemporaneamente está cada vez mais, menos humano. 
No que segue à descrição dos pensadores, outro intelectual que se destaca, mesmo sem carreira acadêmica propriamente dita, é Walter Benjamin (1892-1940). Ele se dedicou ao estudo da cultura, o conhecimento da vida cotidiana e como esta sofria os impactos da modernidade e do capitalismo.

Esses intelectuais também viveram em comum os desafios de seu tempo: os conflitos dos militares com a monarquia da Alemanha, a Crise da República de Weimar, I Guerra Mundial e seus efeitos, o Tratado de Versalhes, o surgimento do Fascismo e a II Guerra Mundial. Dessa forma, diante desses acontecimentos, esse grupo de Intelectuais da chamada Escola de Frankfurt, tinham uma matéria prima gigantesca para ser avaliada do ponto de vista de sua intelectualidade.

Porém, diante dos conflitos do Nazismo e Fascismo todos eles tiveram que fugir da Alemanha, em especial, se refugiando nos Estados Unidos da América. Contudo, a crítica que faziam ao Fascismo e ao Nazismo era muito forte, mas tinham que sustentar as teses de Marcuse, Adorno, Horkheimer e Erich Fromm de que o predomínio da Razão e da Tecnologia nunca não vão conduzir plenamente à Felicidade. Nesse tempo, temos como exemplo o que ocorreu em Auschwitz como triunfo da razão: a destruição do ser humano pelo ser humano por ele mesmo, a barbárie dos campos de concentração, entre outros.

Até aqui se tem apresentado traços gerais da constituição e pensamento desse grupo denominado "Escola de Frankfurt", que ficou também conhecida como Teoria Crítica.

O cenário em que surge a Teoria Crítica se dá em um panorama em que o proletariado não havia produzido a revolução, como havia previsto Karl Marx. Ela é uma alternativa à Teoria Tradicional ou Sociologia Burguesa. É a principal corrente de pensamento para as Ciências Humana do Século XX. Inspirada pelo marxismo, buscava construir uma sociedade sem classes sociais, onde todos vivam com dignidade, compartilhando os bens produzidos socialmente, sem que exista a propriedade privada sobre os meios de produção, porque supõe que estes são a raiz da divisão social em classes sociais.

No âmbito epistemológico, esta teoria se opõe radicalmente à teoria pura que supõe a separação entre o sujeito que conhece a verdade conhecida. A Teoria Crítica tem como enfoque mais que conhecer, transformar o mundo. Para tanto, é necessário dar importância aos fatores psicológicos, sociais e culturais, quanto da abordagem dos temas sociais.

Dois conceitos fundamentais na Teoria Crítica são Alienação e Manipulação. Um indivíduo está alienado quando deixa de pensar por si mesmo em seus próprios interesses, não atua com consciência da realidade. Já o conceito de Manipulação está ligado à manejar, controlar, sob a vontade de outras pessoas através do uso de certos instrumentos, tais como os meios de comunicação. A alienação e a manipulação descrevem a realidade sob um mesmo fenômeno: o emissor manipula e o receptor está alienado. 
Por fim, pode-se dizer que a Teoria Crítica enfoca fundamentalmente as relações sociais, bem como seus conflitos, que provocam revoluções históricas.

\title{
TEORIA CRÍTICA, GIROUX E O CURRÍCULO DE FORMAÇÃO CONTINUADA DE PROFESSORES
}

Entre os autores que se inspiram nas discussões da Escola de Frankfurt, encontramos Henry Giroux, que analisa as implicações da Teoria Crítica na abordagem e desenvolvimento da Pedagogia Crítica, percebendo que as discussões frankfurtianas podem colaborar com os autores da Pedagogia Crítica e na crítica ao Positivismo como racionalidade educativa.

\begin{abstract}
[...] a Escola de Frankfurt oferece uma análise histórica, bem como um arcabouço teórico penetrantes que condenam a cultura do positivismo em seu sentido mais amplo, enquanto, ao mesmo tempo, fornecem "insight" sobre como aquela cultura torna-se incorporada dentro do "ethos" e das práticas escolares. Embora, haja um crescente volume de literatura educacional que é crítica à racionalidade positivistas nas escolas, falta-lhes a sutileza teórica do trabalho de Horkheimer, Adorno e Marcuse. (GIROUX, 1983, p. 24)
\end{abstract}

Giroux apoia-se na Teoria Crítica uma vez que esta, fundamentada, de um lado, na dialética do social e de outro, no particular/pessoal, atende a dimensão discursiva e crítica da consciência sobre a cultura como espaço de construção das relações de domínio político, pedagogia e poder.

Giroux, nos Estados Unidos abordou o Currículo em sua forma teórico-crítica. Sua perspectiva crítica vai na direção de compreender o currículo como espaço de cristalização, uma vez que o mesmo está impregnado de racionalidade técnica, positivismo, utilitarismo na construção de sua abordagem cultural.

Henry Giroux, nasceu em 18 de setembro de 1943 - Estados Unidos. É um crítico cultural estadunidense e um dos teóricos que fundou a Pedagogia Crítica no mesmo país. Seus principais temas de investigação estão relacionados à estudos em Pedagogia Crítica, Estudos Culturais, Política Cultural e Teorias Sociais em Educação, sempre com base na Teoria Crítica da Escola de Frankfurt e, a partir da mesma, produz uma crítica à racionalidade técnica, utilitária e ao positivismo presente no currículo.

Na perspectiva crítica de Giroux, um currículo não pode negar as possibilidades de ação e de participação dos atores escolares, mas é necessário reconhecer o caráter histórico das ações humanas e sociais, bem como da construção de sua epistemologia. Nesse ponto, Giroux ataca a racionalidade técnica e utilitária positivista que busca encontrar no currículo eficiência e burocracia. É nessas formas de currículo que a ideologia dominante se concentra e se reproduz. 
Segundo Giroux, as teorias tradicionais de currículo são espaços ideológicos e, igualmente configurados como espaço de reprodução das desigualdades sociais. É necessário, no entanto, uma teoria que coloque em crítica a epistemologia do currículo, sem cair na rigidez economicista do enfoque marxista. Surge, como alternativa, os estudos da Escola de Frankfurt.Assim, não se pode fazer uma análise crítica do currículo e como o mesmo reproduz a cultura dominante, unicamente verificando que tudo o que acontece na dinâmica do currículo, preparado, programado ou pedagogicamente estruturado, está sob os objetivos daquilo que acontece na economia e na produção. Dessa forma, é necessário no entanto, criticar a estrutura cultural e social.

Quanto à crítica ao fenômeno cultural, que garante a reprodução da cultura dominante, a mesma se justifica pela necessidade de compreender que, uma vez dominante, a reprodução coloca as culturas dominadas em detrimento à dominante e, resta apenas qualificar os processos de resistência ao fenômeno cultural. O lugar de resistência se dá em duas dimensões, seja na vida social (em geral) ou no próprio currículo (em particular). Há nessas duas dimensões, lugar para resistência, rebelião e subversão.

Para Giroux, o currículo tem conteúdo claramente político, ou seja, reside nele a possibilidade da crítica aos arranjos e crenças dominantes.

Sobre a emancipação como conceito curricular, é necessário através de uma dialética da consciência, que o controle e o poder das estruturas sociais reproduzidos pelas instituições reproduzem exercem sobre as instituições educativas, sejam questionadas a partir de três conceitos: esfera pública, intelectual transformador e voz. Uma vez que o currículo é espaço de construção das três esferas, as relações de poder ocorrem na relação que elas estabelecem entre si.

Em primeiro lugar, na categoria Esfera Pública, Giroux ancora-se em Habermas, e argumenta "[...] que o currículo deve funcionar como uma "esfera pública democrática"” (SILVA, 2010, p. 54). O Currículo, dessa forma, inserido nos espaços de democracia, envolve diretamente os professores em um processo de discussão e de participação, onde os pressupostos do senso comum e da vida social sejam postos em questionamento. Para tanto, é necessário que os mesmos sejam capazes de pôr em atividade habilidades discursivas pautadas pela perspectiva crítica.

Sobre a compreensão de Esfera Pública, encontramos a mesma ancorada nos estudos culturais e na abertura das instituições de ensino e do próprio currículo ao público/social.

A importância de que os estudos culturais participem nas esferas públicas de oposição é uma premissa subjacente. Uma práxis contradisciplinar adotada por intelectuais transformadores não seria efetiva se tivesse como público somente as pessoas nas universidades. Em vez disso, ela deveria ocorrer de maneira mais abrangente com o público. Embora muitas universidades sejam instituições públicas, raramente as consideramos parte da esfera pública. (GIROUX, 1997, p. 188)

\begin{tabular}{l|l|l|l|l|l|} 
(C) Rev. Inter. Educ. Sup. & Campinas, SP & v.3 & n.2 & p.255-269 & maio/ago. 2017 \\
\hline
\end{tabular}


Assim, pensa-se que as práticas contradisciplinares podem possibilitar o desenvolvimento de um papel ativo em professores, onde os mesmos possam ser protagonistas do processo formativo continuado. Contudo, antecipa Giroux, necessita-se da resistência, ou seja, uma proposta de formação continuada que, através da crítica promova a identificação e análise dos interesses ideológicos dominantes. Nesse sentido, através da crítica às práticas sociais, o professor se transforma em um intelectual transformador.

Em segundo lugar, na Categoria Intelectual Transformador, Giroux apoia-se em Gramsci, “[...] os professores e as professoras não podem ser vistos como técnicos ou burocratas, mas como pessoas ativamente envolvidas nas atividades da crítica e do questionamento" (SILVA, 2010, p. 54). Diante das novas demandas educacionais, pode-se inferir de que, ao passo que em vão surgindo novas demandas, as reformas educativas buscam excluir a participação dos professores, compreendendo-os apenas como meros executores de propostas governamentais e políticas.

Os professores são considerados mais como obedientes servidores civis, desempenhando ordens ditadas por outros, e menos como pessoas criativas e dotadas de imaginação, que podem transcender a ideologia dos métodos e meios a fim de avaliar criticamente o propósito do discurso e da prática emeducação. (GIROUX, 1992, p. 14)

O desafio, portanto, da intelectualidade do professor está em compreender as diferentes tendências curriculares, unindo-se ao debate que se faz no âmbito público, engajando-se na crítica e na autocrítica. Para isso, é necessário a organização coletiva de classe, discutindo o professor como protagonista de sua formação, inserido os licenciados e os licenciandos no debate.

[...] é importante enfatizar que os professores devem responsabilizar-se ativamente por levantar questões sérias sobre o que ensinam, como devem ensinar e quaisobjetivos mais amplos por que lutam. (GIROUX, 1992, p.22)

Para Giroux, as forças ideológicas de mercado, que compreendem os professores como mero aplicados, levam os professores ao status de técnicos, de racionalidade técnica. De outro modo, é necessário pensar o professor como intelectual transformador. O reconhecimento do professor enquanto intelectual se dá pela percepção da escola como lugar de disputa e de poder, lugar de seleção e exclusão modelados nos princípios da lógica dominante. Nesse espaço há que ser intelectual para realizar o enfrentamento, pois o espaço da escola, em especial do currículo não é neutro. Uma vez em que não há neutralidade na escola, pode-se compreender a função pedagógica do professor como sendo política. Intelectual transformador, nesse sentido, é aquele que insere a escolarização na esfera política da educação.

Em vez de abandonar o conhecimento, os intelectuais transformadores precisam repolitizá-lo. As publicações acadêmicas, critério disciplinar usado para estabelecer o mérito das opiniões profissionais em contraste com aquelas de um público constituído de amadores, não atingem o público. [...] Os intelectuais

\begin{tabular}{l|l|l|l|l|l|}
\hline (C) Rev. Inter. Educ. Sup. & Campinas, SP & v.3 & n.2 & p.255-269 & maio/ago. 2017
\end{tabular}


transformadores devem legitimar a noção de escreverem-se revisões e livros para o público em geral, e devem criar uma linguagem de análise crítica equilibrada por uma linguagem de possibilidade que permita a mudança social. Isto significa que precisamos nos envolver com a leitura política da cultura popular. (GIROUX, 1997, p. 189)

Para que se consiga realizar o enfrentamento das formas dominantes de currículo, Giroux sugere utilizar formas pedagógicas de natureza emancipadora como, por exemplo, possuir um currículo que permita a participação ativa dos sujeitos, desenvolvida através de uma linguagem crítica das possibilidades.

Em terceiro, no conceito de Voz, Giroux recebe influências de Paulo Freire, há a construção de um espaço de escuta e consideração sobre os anseios dos estudantes. Para tanto, surge...

[...] a necessidade de construção de um espaço onde os anseios, os desejos dos pensamentos dos estudantes e das estudantes possam ser ouvidos e atentamente considerados. Através do conceito de 'voz', Giroux concede um papel ativo à sua participação - papel que contesta as relações de poder através das quais se tem essa voz tem sido, em geral, suprimida. (SILVA, 2010, p. 55)

Giroux não apresenta o conceito de voz isolado. Uma vez que o processo educativo escolar não pode ser compreendido como isolado e sim em diálogo, o currículo deve ser pensado como um espaço em que além da voz, há a escuta. A lógica da esfera dominante impõe a voz sobre a escuta, ou seja, na escola muitas vezes, as vozes de estudantes em condição social vulnerável não é ouvida. Assim, até o final da década de 1980, essas vozes não estavam visibilizadas nos currículos e, portanto, não eram escutadas. A partir da década de 1990, as discussões e investigações sobre currículo trazem consigo possibilidades de outras vozes: os enfoques pós-modernos e pós-estruturais (LOPES \& MACEDO, 2010).

Algumas mudanças nesse sentido estão na discussão do currículo em rede, a história do currículo, constituição do conhecimento escolar, entre outros. Ainda, na perspectiva das teorias pós-estruturalistas, encontramos a contribuição significativa do Professor da UFRGS Universidade Federal do Rio Grande do Sul, Tomaz Tadeu da Silva, na obra Documentos de Identidade: uma introdução às Teorias de Currículo, a centralidade da cultura como abordagem curricular.

[...] refere-se a uma abordagem da análise social contemporânea, que passou a ver a cultura como uma condição constitutiva da vida social, ao invés de uma variável dependente, provocando assim nos últimos anos, uma mudança de paradigma nas ciências sociais e nas humanidades [...]. (HALL, 1997. p. 27).

Até aqui, debateu-se sobre a construção do currículo como constituído a partir de sua centralidade cultural. Portanto, não se pode isolar o currículo da compreensão de que a Pedagogia, a Política, Educação e Poder se relacionam também na abordagem cultural do currículo. É nesse espaço que o "currículo envolve a construção de significados e valores 
culturais" (SILVA, 2010, p. 55), bem como, por fim, o currículo caracteriza-se em seus objetivos como [...] um local onde ativamente, se produzem e se criam significados sociais." (SILVA, 2010, p. 55). Entretanto, é necessário pensar o currículo em Giroux como forma de enfrentamento da reprodução na formação continuada de professores.

\section{O ENFRENTAMENTO DA REPRODUÇÃO NA FORMAÇÃO CONTINUADA DE PROFESSORES}

A compreensão que se tem de formação continuada no contexto dos professores, se dá a partir do momento em que se visualiza as práticas pedagógicas como espaço de reflexão. Essas mesmas reflexões levam o professor a repensar o cotidiano escolar, bem como sua identidade profissional. Nesse sentido, é necessário pensar criticamente a formação continuada de professores. Para tanto, a escolha da abordagem crítica de Henry Giroux para pensar a Teoria Crítica de Currículo como enfrentamento de reprodução na formação continuada de professores, se dá a partir do entendimento do currículo como política cultural, onde o referido autor apresenta a "pedagogia da possibilidade" (SILVA, 2010, p.53) como superação da teoria da reprodução. Giroux utiliza-se da compreensão que a Escola de Frankfurt tem sobre a dinâmica da cultura e como esta empreende a crítica da racionalidade técnica.

Ele fala aqui numa "pedagogia da possibilidade" - um conceito que vai se tornar central às teorias de sua fase intermediária. Contra a dominação rígida das estruturas econômicas e sociais sugeridas pelo núcleo duro das teorias críticas de reprodução, Giroux sugere que existem mediações e ações no nível da escola e do currículo que podem trabalhar contra os desígnios do poder e do controle. A vida social em geral e a pedagogia e o currículo em particular não são feitos apenas de dominação e controle. Deve haver um lugar para a oposição e a resistência, para a rebelião e a subversão (SILVA, 2010, p.53)

Dessa forma, a pedagogia da possibilidade, busca investigar, em especial, no enfoque aqui pretendido, se a formação continuada de professores, a partir da compreensão de currículo nesse campo, compreende um enfrentamento da reprodução como um lugar subjetivo de conformismo, onde os sujeitos se conformam e naturalizam esquemas de domínio social. Não se trata de reconhecer a reprodução apenas no âmbito econômico que legitima o conflito de uma classe sobre outra, ou o campo cultural e ideológico, mas o conformismo diante do domínio social, que só pode ser superado a partir da dialética da consciência de classe.

Nesse sentido, um currículo de formação continuada de professores na perspectiva crítica, deve ser a possibilidade da reflexão sobre a prática dos professores - espaço de conformismo - evitando subterfúgios que constituem as teorias de reprodução que se orientam por atitudes passivas e de conformismo com o político, econômico e o culturalmente estabelecido.

v.3

n. 2


Assim, a formação continuada de professores, na maioria das vezes, fomentada por políticas públicas, se constituem a partir de ações descontinuadas, modelos interrompidos, alterados, e o pior de todos, aqueles que, com atitude salvacionista, pretendem ser a solução para todos as questões. Não é de se estranhar, porém, que a maioria dos programas de formação continuada são desenvolvidos em forma de cursos de "treinamento" de professores, assumindo que as teorias de reprodução, fundamentadas na racionalidade técnica, são suficientes para dar conta da dimensão formativa.

[...] uma das maiores ameaças aos professores é o desenvolvimento crescente de ideologias instrumentais que enfatizam uma abordagem tecnocrática para a preparação dos professores e também para a pedagogia de sala de aula. (GIROUX, 1997, p.158)

Com este enfoque, compreende-se que a reprodução está ideologicamente inserida no currículo através de relações sociais de poder, envolvendo significados subjetivos que transformam o professor em processo de formação continuada em um mero receptor passivo profissional.

Há então que se constituir um currículo de formação continuada de professores. Segundo Tardif (2002, p.49),os saberes da experiência "não se encontram sistematizados em doutrinas ou teorias". Esses saberes "formam um conjunto de representações a partir das quais os professores interpretam, compreendem e orientam sua profissão e sua prática cotidiana em todas as suas dimensões". Os saberes oriundos da experiência tem sua origem no trabalho dos professores, onde se mesclam experiências acumuladas individualmente ou compartilhadas coletivamente. Aqui ocorre um conflito inerente da relação entre os saberes da experiência e os demais saberes. Ao descobrirem os limites dos saberes da experiência, os professores demonstram certa rejeição aos demais saberes constitutivos de sua formação profissional.

Sobre os saberes constitutivos do currículo de formação continuada de professores, Freire (2001, p.43) diz de que "[...] na formação permanente de professores, o momento fundamental é o da reflexão crítica sobre a prática". Assim, nessa concepção e, considerando o anteriormente exposto, o saber formativo na abordagem curricular da formação continuada é o exercício da criticidade, com curiosidade epistemológica; de outro modo, a reflexão crítica apoiada na Teoria Crítica sobre os saberes da experiência.

A análise crítica que, ora se insere no contexto de formação continuada, ora em seu currículo, permite superar a reprodução da racionalidade técnica presente no currículo de formação continuada de professores. Esses são os saberes constitutivos do currículo de formação continuada de professores, restando agora, buscar as diferentes compreensões de currículo e suas possibilidades de críticas.

Giroux compreende o currículo como embasado em conceitos de emancipação e liberdade, uma vez que, remanescente da perspectiva marxista na análise social, compreende o currículo como um espaço de conflitos culturais. O currículo passa a ser assim, um instrumento de

\begin{tabular}{|l|l|l|l|l|l|}
\hline (C) Rev. Inter. Educ. Sup. & Campinas, SP & v.3 & n.2 & p.255-269 & maio/ago. 2017 \\
\hline
\end{tabular}


dominação, pois compreende que o mesmo permite contribuir com a reprodução das desigualdades sociais, preconceitos e injustiças. Este mesmo currículo é legitimado pela transmissão ideológica através da obediência de sujeitos passivos, que não podem reagir diante do mesmo.

Nesse sentido, Giroux expõe que os professores bem como os estudantes, tem possibilidade de resistir às práticas sociais dominantes. Para isso, é necessário compreender o ensino como emancipação, democracia e lugar público de justiça social. Assim, Giroux propõe que os professores assumam seu momento histórico, de maneira responsável, buscando transcender a cultura herdada e compreendida como uma racionalidade técnica.

Considerando que a atuação profissional de professores se dá a partir de elementos formativos constituídos nas universidades, orientados por um currículo de formação inicial, e que agora em atividade, assume o imperativo da formação continuada, necessita superar a racionalidade técnica-cientificista por uma racionalidade dialética. Nesse sentido, os espaços de formação continuada são, por excelência, lugares de discussão do currículo como enfrentamento da reprodução.

Nesse sentido, a formação continuada parte do pressuposto de que os professores necessitam superar problemas conceituais e metodológicos quanto à sua formação inicial. Para tanto, enfatiza-se um referencial teórico que dê conta de superar a visão simplista da formação profissional em educação, o que muitas vezes ocorre com rejeição por parte dos professores.

De posse desse sentido, as universidades possibilitam a formação continuada de professores através de atividades de extensão, que buscam, através de uma metodologia dialética, possibilidades de socializar os saberes produzidos em serviço. A reflexão sobre os pontos colhidos em socialização, se dá com base em uma abordagem teórica crítica. Quando isso não acontece, se evidencia que "os programas de treinamento de professores que enfatizam somente o conhecimento técnico prestam um desserviço tanto à natureza do ensino, quanto a seus estudantes" (GIROUX, 1997, p. 159). Nesse sentido, orientados pela racionalidade técnica, os programas de formação são previamente elaborados por especialistas de universidades e executados por para professores.

As instituições de treinamento de professor e as escolas públicas têm, historicamente, se omitido em seu papel de educar os docentes como intelectuais. Em parte, isto se deve à absorção da crescente racionalidade tecnocrática que separa teoria e prática e contribui para o desenvolvimento de formas de pedagogia que ignoram a criatividade e o discernimento do professor. (GIROUX, 1988, p. 23)

Nesse sentido, pode-se considerar que a racionalidade técnica nos processos de formação continuada impõe limites quanto ao desenvolvimento da teoria crítica nesse espaço. Porém, diante das mudanças no contexto do currículo, é necessário pensar os princípios que orientam a formação continuada a partir de sua epistemologia, do social, cultural e dos desafios do enfrentamento da reprodução. 


\section{CONSIDERAÇõES FINAIS}

As reflexões acima constituída apontam para a necessidade de revisão dos currículos de formação continuada de professores. Elas não só traduzem as colaborações de alguns autores da Teoria Crítica para tensionar a reprodução presente no currículo, mas enfocam o processo de formação continuada de professores como constituinte da formação histórica da categoria educação.

Quanto apresentado a construção histórica da Teoria Crítica, a partir da Escola de Frankfurt, se evidencia a necessidade de considerar que, elementos como a naturalização e o conformismo no processo de formação continuada, fazem parte da dinâmica da racionalidade técnica. Elementos como cultura, política, economia são questionados como processos ideológicos presentes nos currículos. Entretanto, este é o legado da Escola: prescrever a crítica na dinâmica da dialética da educação, envolvendo cultura, economia, poder, entre outras relações implícitas nos currículos de formação continuada de professores.

Logo, quando discutido o currículo de formação continuada na perspectiva de Giroux, se evidencia que a pedagogia da possibilidade está em perceber que o mesmo campo do currículo, permeado de relações de reprodução, também é, por excelência, um espaço de discussão crítica. No entanto, isto remete a pensar o professor como intelectual.

Por último, quando se discute a formação continuada de professores, envolvendo elementos do currículo bem como dos programas de formação, mantém-se a crítica anterior, apresentando a reprodução e seu desenvolvimento não apenas no currículo, mas em toda dinâmica formativa.

Concluindo, porém, as contribuições de Giroux como remanescente da Teoria Crítica da Escola de Frankfurt são, reconhecidamente, a expressão das possíveis articulações que visam o enfrentamento da reprodução no currículo de formação de professores.

\section{REFERÊNCIAS}

FROMM, Erich. A importância da diferença entre ter e ser. Ter ou Ser? 2. ed. Rio de Janeiro: Zahar, 1977.

ADORNO, Theodor W. HORKHEIMER, Max. Dialética do Esclarecimento. Rio de Janeiro: Zahar, 1985.

SILVA, Tomaz T. da. Documentos de Identidade: uma introdução às Teorias de Currículo. $3^{\mathrm{a}}$ ed. Belo Horizonte: Autêntica, 2010. 
GIROUX, Henry. Os professores como intelectuais - Rumo a uma pedagogia crítica da Aprendizagem. Trad.: Daniel Bueno. Porto Alegre: Artes Médicas, 1997.

GIROUX, Henry. Escola crítica e política cultural. 3. ed. Trad. Dagmar Zibas. São Paulo: Cortez/Autores Associados, 1992. Coleção Polêmicas do nosso tempo.

HALL, Stuart. A centralidade da cultura: notas sobre as revoluções culturais do nosso tempo. Educação \& Realidade, Porto Alegre, v.22, n.2, p. 15-46, jul./dez. 1997.

TARDIF, Maurice. Saberes Docentes e Formação Profissional. Petrópolis: Vozes,2002.

FREIRE, Paulo. Pedagogia da Autonomia: saberes necessários à prática educativa. 19a Ed. São Paulo: Paz e Terra, 2001.

\footnotetext{
${ }^{\mathrm{i}}$ Sobre o autor

Rudinei Barichello Augusti

E-mail: rudinei.augusti@gmail.com / ORCID: http://orcid.org/0000-0003-3113-3570

Universidade Regional do Noroeste do Estado do Rio Grande do Sul - Brasil

Mestre e Doutorando em Educação nas Ciências pela Universidade Regional do Noroeste do Estado do Rio Grande do Sul [UNIJUI].
} 